\title{
Reproduction Status and Population Dynamic of Kuantan Cattle in the Kuantan Singingi Regency
}

\author{
Yendraliza $^{1}$, Rodiallah $\mathrm{M}^{1}$, Astuti $\mathrm{T}^{2}$, Elfawati $^{1}$ \\ ${ }^{1}$ Department of Animal Science, Faculty of Agriculture and Animal Science, Universitas Islam Negeri Sultan Syarif Kasim Riau \\ Jl. H.R. Soebrantas KM 15 Simpang Baru, Pekanbaru, Riau, Indonesia 28293 \\ ${ }^{2}$ Departement of Animal Science, Faculty of Agriculture, University Mahaputra Muhammad Yamin \\ Jl. Jendral Sudirman No.6, Solok, West Sumatera. Indonesia. \\ E-mail: yendraliza@uin-suska.ac.id
}

(received 29-07-2020; revised 26-10-2020; accepted 11-11-2020)

\begin{abstract}
ABSTRAK
Yendraliza, Rodiallah M, Astuti T, Elfawati. 2020. Status Reproduksi dan dynamic populasi sapi Kuantan di Kabupaten Kuantan Singingi. JITV 25(4): 162-172. DOI: http://dx.doi.org/10.14334/jitv.v25i4.2541

Efisiensi reproduksi, struktur populasi, dinamika populasi, natural increase, estimasi output merupakan salah satu tolak ukur menentukan ternak dan wilayah tersebut dapat dijadikan sumber bibit. Tujuan penelitian ini adalah untuk menentukan efisiensi reproduksi, dinamika populasi, natural increase dan estimasi output populasi sapi Kuantan di Kabupaten Kuantan Singingi, Provinsi Riau, Indonesia. Penelitian menggunakan 311 ekor sapi Kuantan dan 99 orang peternak sapi Kuantan. Pengambilan sampel menggunakan purposive sampling dengan metode survey dan pengamatan langsung, data dianalisis secara deskriptif. Parameter yang diukur adalah efisiensi reproduksi, natural increase, estimasi output dan dinamika populasi sapi Kuantan. Hasil penelitian memperlihatkan bahwa efisiensi reproduksi sapi Kuantan adalah $1.04 \%$, natural increase 5.14\%, imbangan jantan dan betina 1:5, nilai NRR jantan $50 \%$ dan NRR betina $100.56 \%$, total ternak yang keluar $18.69 \%$ dan total ternak yang masuk $18.69 \%$, nilai output $48.88 \%$ dan estimasi dinamika populasi $2.85 \%$. Kesimpulan, reproduksi sapi kuantan belum efisien dengan pertambahan alami sapi kuantan amat rendah dan jumlah ternak penganti sapi jantan dan betina belum terpenuhi. Disarankan untuk tidak mengeluarkan sapi Kuantan dalam 5 tahun kedepan untuk menjaga keseimbangan populasi.
\end{abstract}

Kata Kunci; Dinamika Populasi, Natural Increase, Output, Reproduksi

\section{ABSTRACT}

Yendraliza, Rodiallah M, Astuti T, Elfawati. 2020. Reproduction status and population dynamic of Kuantan cattle in the Kuantan Singingi Regency. JITV 25(4): 162-172. DOI: http://dx.doi.org/10.14334/jitv.v25i4.2541

The purpose of this study was to determine reproductive efficiency, population dynamics, natural increase and estimated output of the Kuantan cattle in the Kuantan Singingi Regency, Province of Riau, Indonesia. A total of 311 Kuantan cattle and 99 Kuantan cattle farmers were used in this study through a survey study. Respondent samples were taken from seven districts. Data sampling using purposive sampling with survey methods. Data collection was carried out by interviewing farmers and observing and was analyzed descriptively. Parameters measured were reproductive efficiency, natural increase, estimated output and population dynamics of Kuantan cattle. Results showed that the reproductive efficiency of Kuantan cattle was $1.04 \%$, natural increase $5.14 \%$, the balance of male and female 1: 5 , the value of male NRR 50\% and female NRR $100.56 \%$, total cattle out $18.69 \%$ and total incoming cattle $18.69 \%$, output value $48.88 \%$ and estimated population dynamics $2.85 \%$. In conclusion, Kuantan cattle reproduction has not been efficient with the natural increase of the Kuantan cattle was very low, and the replacement stock availability for male and female cattle has not been fulfilled. It is recommended not to release Kuantan cattle in the next 5 years to maintain population balance.

Key Words: Natural Increase, Output, Population Dynamic, Reproduction

\section{INTRODUCTION}

The Indonesian policies about meat selfsufficiency base on local resources start in 2000-2010, but unsuccessful because of a lack of information about local cattle populations, geographical distribution, and genetic characteristics. The native cattle play a vital role in Indonesia's socioeconomic, conservation and breeding programs for Indonesian cattle breeds must be well designed based on their potential and genetic information (Agung et al. 2019). The Kuantan cow is one of Indonesia's local cows from Riau with a decree Ministry of Agriculture Indonesia as No. 1052/kpts/S.R.120/10/2014. Kuantan cattle are smaller in size than Aceh cows and Bali cows. The results of genetic distance analysis show that Kuantan and Pesisir cattle have close genetic values and are in the Bos indicus group (Hidayati et al. 2016). Kuansing Regency 
is one of the original areas of Kuantan cattle. Kuantan cattle have the potential to be developed because they are raised by breeders in rural areas of the Kuantan and Indragiri rivers, easily adaptable to low feed nutrition and resistant to disease (Department of Animal Husbandry and Animal Health of Riau Province, 2019). The same data source states that the population of Kuantan cattle in the Kuansing Regency has not increased from 2014(1.179 heads) to 2018 (1.278 heads). Evaluation of population growth or population dynamics to maintain population balance is important (Rohyan et al. 2016). Estimated output data, natural increase, birth rates, and livestock mortality are used to determine livestock breeding patterns (Warwick et al. 1983). The age composition of the livestock population is needed to determine the need for replacement cattle in one year. The population dynamics will give clues on the population viability in the future (Wang et al. 2016). Breeding patterns are closely related to the appearance of livestock reproduction. Literature investigation, research that has been done on Kuantan cattle is sperm quality in Kuantan cattle (Jiyanto \& Anwar, 2019). The Population dynamics of Pesisir cattle was carried out in (Putra et al. 2015), Madura cattle (Kutsiyah, 2017), Bali cattle (Budiarto et al. 2013), breed Ongole (Kusuma et al. 2017); (Rohyan et al. 2016) and Pasundan cattle (Said et al. 2017). Growth data, population dynamics, natural increase and reproductive efficiency of Kuantan cattle have not been done. This data is needed to determine the ability of livestock inbreeding and the ability of the region to be a source of breeders, substitute livestock and fattening. The purpose of this study was to determine reproductive efficiency, population dynamics, output, natural increase and mutation of Kuantan cattle in the Kuansing District.

\section{MATERIALS AND METHODS}

This research was conducted in Benai, Inuman, Pangean, Cirenti, Singingi Hilir, and Singingi Districts, Kuantan Singingi (Kuansing) Regency for six months, starting from June to November 2019 (Figure 1). The selection of research locations is based on the largest number of Kuantan cattle populations. The materials used were 99 farmers owning Kuantan cattle with 311 Kuantan-cows after parturition. Kuantan cattle are grazing long days and placed in the barns at night. The feed given was a grass field, lict salt as a feed additive, drinking water was given ad-libitum.

This research location and respondent were the determination of the purposive sampling method. They were selected based on the Kuantan cattle population. The respondent sample was Kuantan cattle farmers who had 5 years' experience in reproduction management. Data were collected by direct interviews with respondents using questionnaires and observation of livestock for body condition after parturition. The interviews were done about the identity of the farmer, the number of livestock ownership, livestock population, the first mating age, rearing limitation of age, weaning age, first mating after post-partum, calving interval, number of calves cows, mutations of livestock and the age of one year, and the method of mating.

\section{Data analysis}

The reproductive data were analyzed quantitatively by displaying the mean and standard deviation. The data number of livestock, population structure be used to calculate the natural increase, net replacement rate, and estimated output through the livestock breeding approach.

Population structure was calculated and analyzed according to Warwick et al. (1983), as follow:

Number of adult cattle (\%)

$$
=\frac{\text { Number of adult cattle }}{\text { Number of the adult population }} \times 100 \%
$$

Calving rate based on female adult cattle or calf crop was calculated based on the number of female adults and number of population:

Calving rate based on the number of female adults (\%)

$$
\frac{\text { Number of calves }}{=\text { Number of female adults }} \times 100 \%
$$

Calving rate based on the number of population (\%)

$$
=\frac{\text { Number of calves }}{\text { Number of population }} \times 100 \%
$$

Mortality(\%)

$$
=\frac{\text { Number of death cattle/year }}{\text { Number of population/year }} \times 100 \%
$$

Natural Increase

$$
\text { calving rate base on population - mortality }
$$

Net Replacement Rate $(\mathrm{NRR})=$

number of replacement young cattle candidates need for replacement cattle $x 100 \%$

If NRR $<100 \%$, then the need for substitute livestock is not fulfilled, conversely if NRR> $100 \%$, the need for replacement livestock is fulfilled

Replacement stock necessary for male cattle $(\%)$ is obtained from the number of adult males (heads) divided by the rearing limitation age of male cattle (years). Replacement stock necessary for female cattle (\%) is obtained from the number of adult females (heads) divided by the rearing limitation age of female cattle (years). 


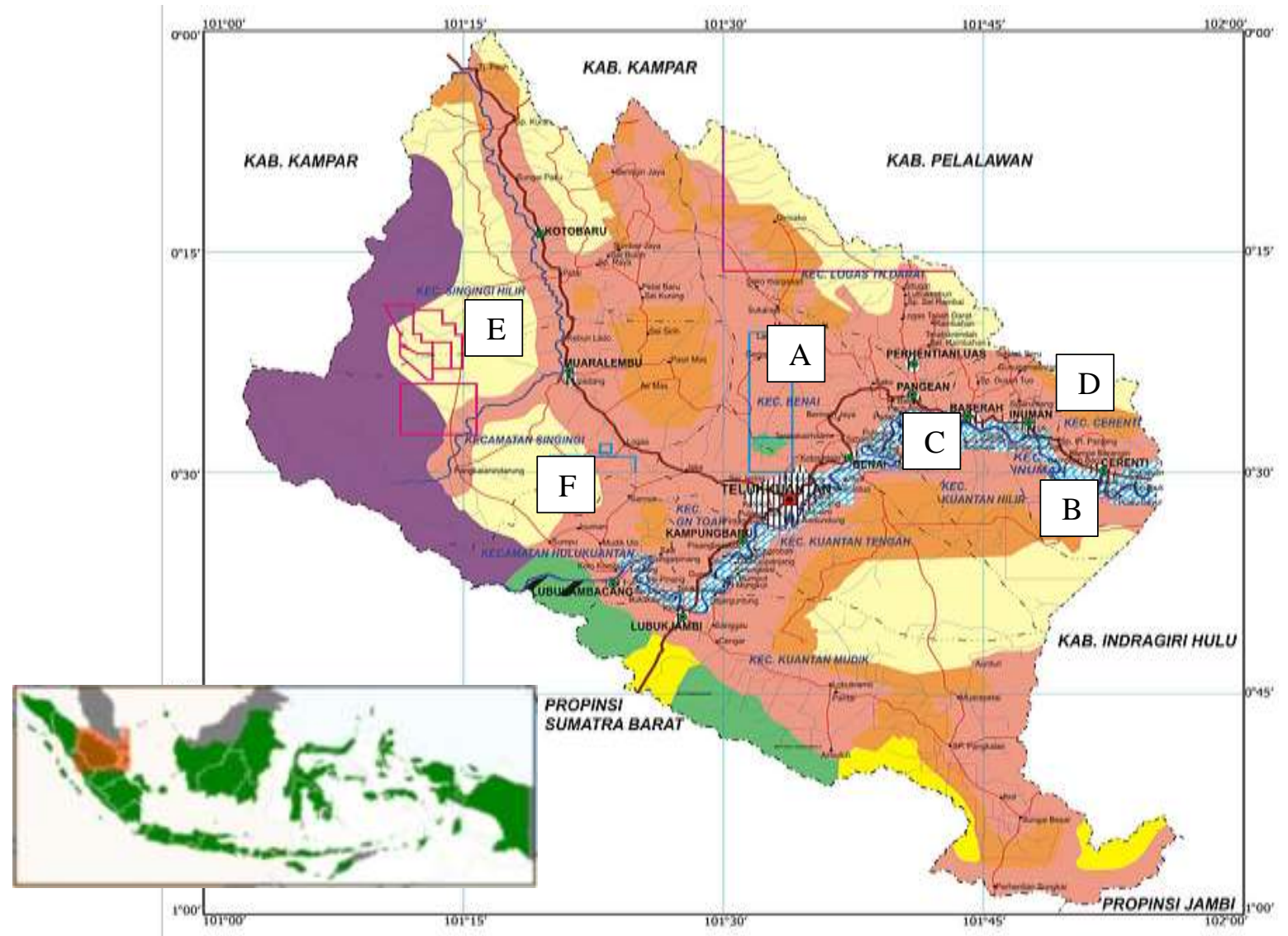

Figure 1. Location of the research site at six Districts at Kuantan Singingi Regency, Riau Province, Indonesia consisted of: A. Benai, B. Inuman, C. Pangean, D. Cirenti, E. Singingi Hilir and F. Singingi districts.

Population dynamics were estimated from the Kuantan cattle population data in Kuansing District over the past five years with time series analysis of the least-squares method with a linear polynomial equation.

The cattle output rate was calculated as the male cattle of replacement $(\%)+$ the female cattle of replacement $(\%)+$ the culling cattle of male + the culling cattle of the female.

Female cattle growth

$=\frac{\text { number of female cattle calves (heads) }}{\text { total population (heads) }} \times 100 \%$

Male cattle growth

$=\frac{\text { number of male cattle calves (heads) }}{\text { total population (heads) }} \times 100 \%$

The rest of the replacement for young male cattle was calculated as male growth (\%) - the replacement stock necessary for male cattle (\%). Where the rest of the replacement for young female cattle was calculated as female growth $(\%)$ - the replacement stock necessary for female cattle $(\%)$.
The culling male cattle were calculated as the rest of the replacement for young male cattle, where the culling female cattle was calculated as the rest of the replacement for young female cattle.

Reproduction Efficiency (RE) was measured according to Sumadi (2001) as:

(calving interval x number of calf)/((first -

time calving - first time mating) +

(calving interval - duration of pregnancy) ) x 100\%

\section{RESULTS AND DISCUSSION}

\section{Characteristics of Kuantan cattle breeders}

The average age of respondents is $36-49$ years, with the greatest level of education being senior high school. have 10-15 years of experience raising livestock with 49 cattle per family. The main occupation of the respondents is raising livestock with 4-5 laborers per family carried out by family members themselves. The average age of respondents is still a productive age with a longer experience of raising livestock and a relatively 
high level of education allows for more learning, accepting technological innovations towards better change, but the knowledge they gain is only from experience. So that management is carried out only from generation to generation. This can be seen from the management of feed, which is done only by providing field grass without concentrate. For breeding management, breeders have already carried out livestock germ selection (Figure 2). But not all farmers do recording, judging and replacement stock. Characteristics of respondents are an indicator to determine the ability of farmers to manage their livestock (Romjali 2018).

\section{Kuansing land area}

The area of pasture land in the Kuansing Regency is 1,831 Ha (Table 1). The capacity of pasture in the Kuansing Regency is 5.016,44 ST or equivalent to 5.016 adult cattle with a weight of $250 \mathrm{~kg}$. The current population of Kuantan cattle is 1.278 (estimated data), so there is an opportunity to increase the population of $3.738,44$ adult cattle. This opportunity becomes greater if the area of pasture is combined with other agricultural areas such as plantations, paddy fields, yards, and fields. This condition allows the Kuansing regency to become a place for developing Kuantan cattle.

\section{Reproduction characteristics of Kuantan cattle}

Characteristics of livestock reproduction are useful for knowing the reproductive ability of livestock to produce subsequent offspring. The mean age at first mating in male and female Kuantan cattle was $24.5 \pm$ 3.03 months and $45.6 \pm 1.93$ months (Table 2). This value is greater than Pesisir cows (22.67 \pm 2.53 months and $23.02 \pm 1.46$ months) (Putra et al. 2015) and Madura cattle (21.12 \pm 0.16 months) (Kutsiyah, 2017) and Ongole crossbred cattle in Kebumen (26.87 \pm 5.51 months) (Rohyan et al. 2016). This was due to differences in maintenance and maintenance objectives carried out by each farmer. The first calving Kuantancows on $54.5 \pm 1.53$ months, it was longer than Madura cattle (31.97 \pm 6.43 months), Pesisir cattle (33.83 months) Ongole crossbred cattle $(37.15 \pm 5.87$ months), and Bali cattle (31.92 \pm 0.19 months) (Kutsiyah, 2017; Putra et al. 2015; Rohyan et al. 2016; Samberi et al. 2010)

The age of first calving of Kuantan cattle was older than that of other cattle due to late first mating. Likewise, the weaning age of Kuantan cattle (11.5 \pm 3.2 months) was older than that of Pesisir cattle $(5.57+$ 0.31 months) (Putra et al. 2015), Madura cattle (5.06 \pm 0.88 months) (Kutsiyah, 2017), PO cattle (3.97 \pm 1.10 months) and Bali cattle (4.41 \pm 0.32 months) (Samberi et al. 2010). Although the age weaning of Kuantan cattle was high, it did not affect the age of first mating after giving birth $4.8 \pm 2.2$ months.

The first mating interval after giving birth of Kuantan cattle was shorter than Pesisir cows (5.30+0.51 months) (Putra et al. 2015), the same as PO cattle (4.52 \pm 1.59 months) (Rohyan et al. 2016) and longer than Bali cattle $(3.53 \pm 0.29$ months). Likewise, the calving interval of Kuantan cattle (14.74 \pm 9.2 months) is not much different from PO cattle (14.32 \pm 1.93 months), higher than Bali-cows (13.68 \pm 0.51 months) and lower than Pesisir cattle (16.20 \pm 0.92 months). These

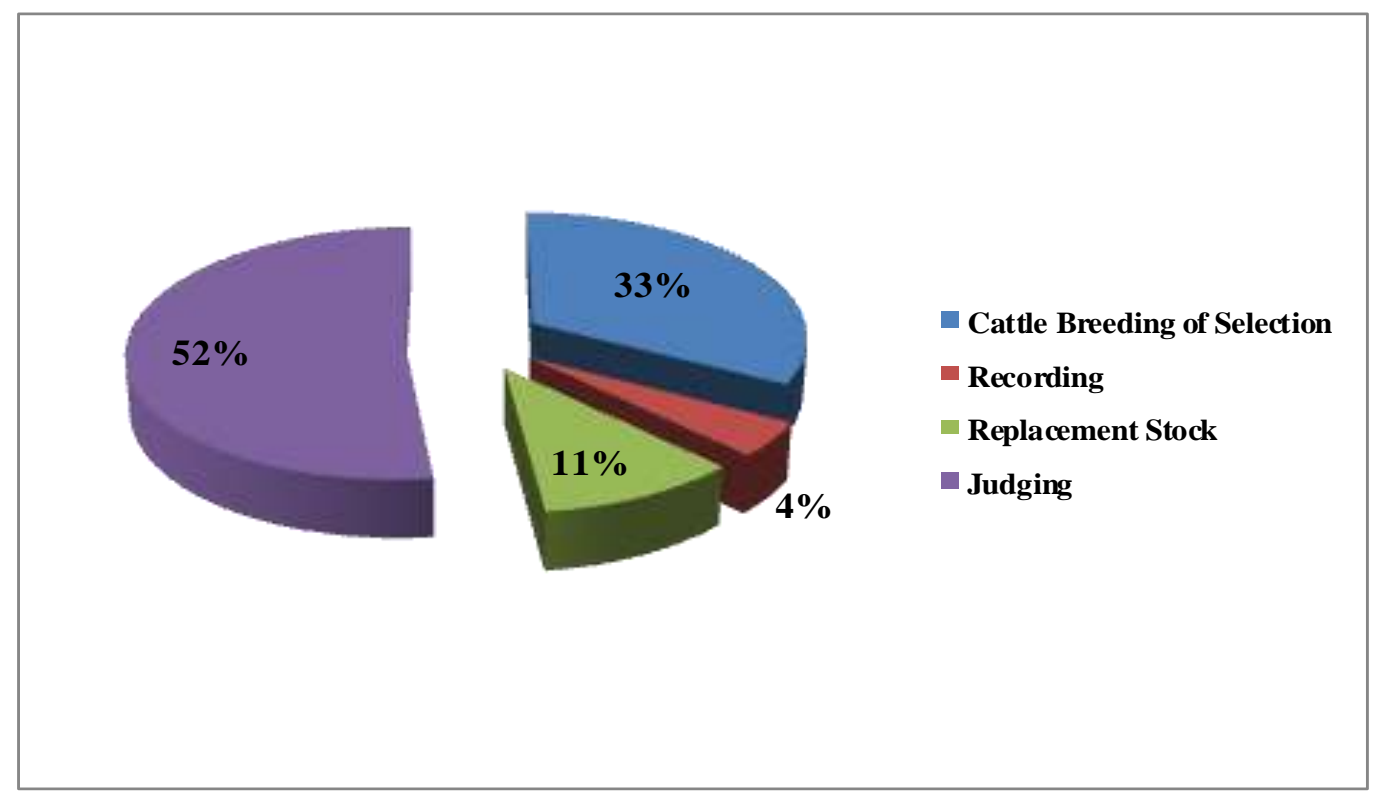

Figure 2. Breed of management carried out by breeders 
Table 1 Kuansing land area profile

\begin{tabular}{lcc}
\hline \hline Usage Type & Large (Ha) & Percentage $(\%)$ \\
\hline Land of paddy fields & 17.298 & 2.94 \\
The yard & 51.163 & 8.69 \\
The moor & 59.083 & 10.03 \\
Plantation land & 402.738 & 68.38 \\
Pasture & 1.831 & 0.31 \\
Temporary land has not been worked on & 35.192 & 5.98 \\
Other & 21.682 & 3.68 \\
Total & 588.987 & 100,00 \\
\hline
\end{tabular}

Table 2. Reproduction characteristics of Kuantan cattle

\begin{tabular}{|c|c|}
\hline Description & Average $\pm \mathrm{DS}$ \\
\hline \multicolumn{2}{|l|}{ First Mating Age (Month) } \\
\hline Sire & $24.5 \pm 3,03$ \\
\hline Mare & $45.6 \pm 1,93$ \\
\hline First Calving Age (Month) & $54.5 \pm 1.53$ \\
\hline Conception Period (Month) & $9.9 \pm 2.5$ \\
\hline Calving Interval (Month) & $14.74 \pm 9.2$ \\
\hline Weaning Age (Month) & $11.5 \pm 3.2$ \\
\hline Post-Partum Mating (Month) & $4.8 \pm 2.2$ \\
\hline \multicolumn{2}{|l|}{ Mating Method } \\
\hline Artificial insemination $(\%)$ & 8.3 \\
\hline Natural mating (\%) & 92.6 \\
\hline \multicolumn{2}{|l|}{ Number of calves dam } \\
\hline Male (Heads) & 111 \\
\hline Female (Heads) & 333 \\
\hline Total (Heads) & 444 \\
\hline \multicolumn{2}{|l|}{ Body condition after parturition } \\
\hline Fatty $(\%)$ & 10 \\
\hline Medium (\%) & 25 \\
\hline Thin $(\%)$ & 75 \\
\hline \multicolumn{2}{|l|}{ Rearing limitation age (years) } \\
\hline Sire & 2.26 \\
\hline Mare & 4.31 \\
\hline Respondents amount (People) & 121 \\
\hline Dam total on population (Heads) & 180 \\
\hline Sample population (Heads) & 311 \\
\hline Reproductive Efficiency (\%) & 102.79 \\
\hline
\end{tabular}


Table 3. The natural increase of Kuantan cattle in Kuansing Regency

\begin{tabular}{lc}
\hline \hline Description & Average \\
\hline Population (heads) & 311 \\
Dam population (heads) & 180 \\
Dam population on average (\%) & 57.87 \\
Calving (heads) & 44 \\
Male (heads) & 11 \\
On dam population (\%) & 6.1 \\
On average population (\%) & 3.53 \\
Dam (heads) & 33 \\
On dam population (\%) & 18.33 \\
On average population (\%) & 10.6 \\
Calving rate & 24.44 \\
On dam population $(\%)$ & 14.14 \\
On average population (\%) & 5.00 \\
Mortality & $5.14 \%$ \\
Total (heads) & 28 \\
Mortality on population (\%) & \\
Natural Increase & \\
\hline
\end{tabular}

Table 4. Population structure of Kuantan cattle in Kuansing Regency

\begin{tabular}{|c|c|c|c|}
\hline \multirow[b]{2}{*}{ Composition } & \multicolumn{3}{|c|}{ Total } \\
\hline & Heads & $\begin{array}{c}\text { Animal } \\
\text { Unit }\end{array}$ & $(\%)$ \\
\hline \multicolumn{4}{|l|}{ Mature } \\
\hline Male & 36 & 36 & 11.58 \\
\hline Female & 180 & 180 & 57.88 \\
\hline Total & 216 & 216 & 69.36 \\
\hline \multicolumn{4}{|l|}{ Young } \\
\hline Male & 9 & 4.5 & 2.89 \\
\hline Female & 42 & 21 & 13.50 \\
\hline Total & 51 & 25.5 & 16.39 \\
\hline \multicolumn{4}{|l|}{ Calf } \\
\hline Male calf & 11 & 2.75 & 3.54 \\
\hline Female calf & 33 & 8.25 & 10.61 \\
\hline Total & 44 & 11 & 14.15 \\
\hline Number of respondents (person) & 99 & & \\
\hline Number of livestock ownership/respondent (heads) & 4.32 & & \\
\hline
\end{tabular}


Table 5. Mutation of Kuantan cattle in Kuansing Regency

\begin{tabular}{|c|c|}
\hline Description & Percentage $(\%)$ \\
\hline Total population (Heads) & 1,118 \\
\hline \multicolumn{2}{|l|}{ Livestock entry/purchase } \\
\hline \multicolumn{2}{|l|}{ Mature } \\
\hline Male $(\%)$ & 5 \\
\hline Female $(\%)$ & 8 \\
\hline \multicolumn{2}{|l|}{ Young } \\
\hline Male $(\%)$ & 103 \\
\hline Female $(\%)$ & 18 \\
\hline \multicolumn{2}{|l|}{ Calf } \\
\hline Male $(\%)$ & 11 \\
\hline Female $(\%)$ & 20 \\
\hline Total (heads) & 165 \\
\hline The number of cattle entering in population & 14.75 \\
\hline \multicolumn{2}{|l|}{ Cattle out $(\%)$} \\
\hline \multicolumn{2}{|l|}{ Mature } \\
\hline Male (\%) & 34 \\
\hline Female $(\%)$ & 21 \\
\hline \multicolumn{2}{|l|}{ Young } \\
\hline Male (\%) & 106 \\
\hline Female $(\%)$ & 35 \\
\hline \multicolumn{2}{|l|}{ Calf } \\
\hline Male $(\%)$ & 4 \\
\hline Female $(\%)$ & 9 \\
\hline Total (Heads) & 209 \\
\hline The number of livestock that come out of the population & 18.69 \\
\hline \multicolumn{2}{|l|}{ Slaughter of cattle $(\%)$} \\
\hline \multicolumn{2}{|l|}{ Mature } \\
\hline Male $(\%)$ & 98 \\
\hline Female $(\%)$ & 24 \\
\hline Total the slaughter of cattle (Heads) & 122 \\
\hline The number of cattle slaughtered against in population (\%) & 10.9 \\
\hline
\end{tabular}

characteristics show that Kuantan cattle have good fertility to be developed as breeding cattle Romjali (2018) states that Indonesian local cattle can reproduce well in conditions of environmental stress that are less supportive than cattle originating from subtropical areas and this value will be an important point in local cattle breeding.

The reproduction efficiency of the Kuantan cattle was $102.79 \%$, higher than PO cattle at $91.8 \%$, Bali cattle $88.38 \%$ and Madura cattle $93.21 \%$ (Rohyan et al. 
2016). This percentage showed that the reproduction of Kuantan cattle was not efficient. The higher the percentage of reproductive efficiency, the age of first mating and age of first cow breed is also high (Suyadi et al. 2014). This value becomes a barometer that livestock reproduction management is not good. The availability of feed and mating system in Kuantan cattle is not so good that their reproduction was inefficient in producing off-springs. This can be seen from the condition of the Kuantan-cows that were thin after giving birth. Proper maintenance management will result in lower reproductive efficiency because adequate intake of energy, protein, vitamins, and minerals will make reproductive efficiency optimal (Bindari et al. 2013).

\section{Natural Increase (NI)}

The natural increase value of Kuantan cattle in the Kuansing Regency was $5.14 \%$ (Table 4). This value was low because Samberi et al. (2010) stated that the NI value consists of three categories, low if NI $\leq 50 \%$, medium if $51 \% \leq \mathrm{NI} \leq 80 \%$, high if $\mathrm{NI} \geq 81 \%$. This value is lower than some local Indonesian cattle, Pasundan cattle ( $18.46 \%$ ) (Said et al. 2017), PO cattle (44.68\%) (Rohyan et al. 2016), Pesisir cattle (29.46\%) (Putra et al. 2015). This difference is due to the different breeding systems and the livestock environment. This NI value is one measure to see an increase or decrease in a livestock population (Warwick et al. 1983). The low NI value of Kuantan cattle was due to the low birth rate compared to the number of existing cows. Sumadi et al. (2002) state that the NI value is influenced by birth rates and livestock mortality in one area. The low NI of Kuantan cattle showed that the management and handling of productive adult females were not very good, so from 180 productive females, cattle that were used as research samples only 44 adult females gave birth equivalent to $24 \%$ of productive females. Some factors that were thought to cause a low percentage of productive adult female cattle were the number of males available was reduced due to slaughtering or sold due to the expends of school children. In addition, slaughtering due to customary celebrations and religious holidays cause the depletion of adult male cattle in the field. In addition, the high mortality rate of livestock causes a reduction in the number of males cattle in the field (Budiarto et al. 2013).

\section{Population structure of Kuantan cattle}

The population structure of Kuantan cattle in the Kuansing Regency was dominated by $81.9 \%$ female cattle (Table 4). This is an indication that the purpose of raising Kuantan cattle is to produce offspring and is a side job (Syatra et al. 2016). The sex ratio of Kuantan cattle in this study was 1 male to 5 females. This sex ratio is different from Maremma animals in Perugia (1: 1.58) (Fioretti et al. 2020), Pesisir cattle (Putra et al. 2015).

and beef cattle in Poso (Tanari et al. 2011). The large composition of female livestock in one area is one indicator that the area can be used as a breeding center (Sumadi, 2001) and the purpose of maintaining livestock of farmers is to breeding. Total livestock ownership was 4 adult livestock and 1 off-spring. The number of livestock ownership in Kuantan is different from the amount of buffalo ownership in Pariaman regency (2.43) (Putra et al. 2017). This difference is due to different types of livestock and motivation to raise an animal.

\section{Composition of Kuantan cattle mutations}

The composition of the Kuantan cattle mutation was the process of movement of animals between the same region or in different areas with the buying and selling process. Data in Table 5 shows that the outgoing cattle $(28.9 \%)$ were higher than the incoming cattle (14.75). This is one indicator that the region is a livestock producer. The weakness of this study area was that livestock production was not proportional to livestock expenditure so that the natural increase in Kuantan cattle was low. Draining of Kuantan-cows, both male and female. This can be seen from the number of productive female livestock sold. This condition will affect the balance of the population in the next few years because poor livestock was maintained for a longer time.

\section{Net Replacement Rate (NRR)}

The number of male and female livestock birth in Kuantan cattle did not meet the needs of substitute animals (male NRR, 50\%; female NRR 100.56\%) (Table 6). The need for substitute livestock is said to be sufficient if the NRR value> $100 \%$ (Sumadi et al. 2002).

The NRR value is used to determine whether the number of livestock birth can cover the need for substitute livestock so that the population remains balanced. NRR value is closely related to NI value. The greater the value of NI, the greater the NRR value. The low NRR in Kuantan bulls showed that there was a depletion of Kuantan bulls in the Kuansing regency. This was because of the availability of a bull to replace only 0.5 times the need. This condition can be stated that the Kuansing regency lacks male cattle. While the availability of female Kuantan cows to replace only 1 time. This value is better than the value of bulls (Sumadi et al. 2002). The low NRR value of this 
Table 6. The net replacement rate for Kuantan cattle in Kuantan Singing regency

\begin{tabular}{lc}
\hline \hline Description & Percentage (\%) \\
\hline Replacement stock necessary (\%) & \\
Male & 18 \\
Female & 41.76 \\
NRR & \\
Male & 50 \\
Female & 100.56 \\
\hline
\end{tabular}

Table 7. Estimated of Kuantan cattle output in the Kuantan Singingi regency in 2018

\begin{tabular}{lc}
\hline \hline Description & Percentage $(\%)$ \\
\hline $\begin{array}{l}\text { The rest of the replacement } \\
\text { (young) }\end{array}$ \\
Male & 12,55 \\
Female & -23.43 \\
\hline Availability Replacement & \\
Male & 18 \\
Female & 41.76 \\
\hline Culling cattle & \\
Male & 18 \\
Female & 41.76 \\
\hline Total Output & 48.88 \\
\hline
\end{tabular}

Table 8. Population dynamics of Kuantan cattle

\begin{tabular}{llc}
\hline \hline Years & Population & $\begin{array}{c}\text { Change in Population } \\
(\%)\end{array}$ \\
\hline 2014 & 1179 & - \\
2015 & 1176 & -0.26 \\
2016 & 1118 & -5.19 \\
2017 & 1218 & 8.21 \\
2018 & 1278 & 4.69 \\
2019 & 1265 & -1.03 \\
\hline
\end{tabular}

Kuantan cattle in the Kuansing regency is an indication that the Kuansing area cannot be called the source area of the Kuantan cattle.

The NRR of Kuantan cattle in this study was lower than the NRR of Pasundan cattle (807\%) (Said et al. 2017), PO cattle in Kebumen were $253 \%$ for females cattle and $1,207 \%$ for males cattle (Rohyan et al. 2016) and not much different from Madura cattle on Sapudi island 96\% NRR for male cattle, $126 \%$ NRR for female cattle) (Kutsiyah, 2017). This difference was due to differences in management, food availability and socio-economic community (Warwick et al. 1983).

\section{Kuantan cattle output}

The output of Kuantan cattle (48.88\%) (Table 7) greater than the NI value of Kuantan cattle (5.14\%). This was an indicator that there was no increase in the population of Kuantan cattle in the Kuansing regency (Sumadi, 2001). The development of the population of Kuantan cattle in the Kuansing regency has begun to be disrupted so that for a while the region was not able to produce Kuantan cattle. For this reason, it is necessary to manage breeding patterns by increasing birth rates, reducing mortality, shortening maintenance time and fattening the rejected animals to prepare substitute livestock for parent-stock. The negative residual replacement in male cattle shows that there was a tendency for people to sell or slaughter cattle before two years old (Putra et al. 2015). The output of Kuantan cattle was higher compared to Bonsamara cattle in Brazil by $-3.58 \%$ (Santana et al. 2012), Buffalo in Brazil by $12.5 \%$ (Ferraz et al. 2015), Bali cattle in Papua by $13.11 \%$ (Samberi et al. 2010), Pesisir cattle by $20.25 \%$ (Putra et al. 2015) and Madura cattle $30.75 \%$ (Kutsiyah, 2017). This difference was due to different regional conditions resulting in different feed quality, maintenance systems and socioeconomic (Budiarto et al. 2013).

\section{Population dynamics of Kuantan cattle}

The population dynamics of Kuantan cattle in the Kuansing Regency from 2014 to 2018 was only $2.84 \%$ (Table 8) (Department of Animal Husbandry and Animal Health of Riau Province, 2019). This value was not significant to increase the livestock population when compared to the number of available parentstock.

The prediction population of Kuantan cattle for 2020 to 2023 with regression polynomial, $\mathrm{Y}=$ $2.0544 \mathrm{x}^{3}+30.617 \mathrm{x}^{2}-105.42 \mathrm{x}+1259.5$, with $\mathrm{R}^{2}=0.82$ (Figure 3). The amount of Kuantan cattle availability was smaller than the number of Kuantan cattle needed so this indicates that Kuansing Regency is not yet suitable as a source of Kuantan cattle. The population dynamics is a reflection of the reproductive appearance of Kuantan cattle. The low reproductive performance will reduce the increase in livestock population (Gunawan et al. 2011). The low dynamic population will result in generation loss (Makina et al. 2015). One effort to improve livestock reproduction is by selecting livestock germs from both prospective mothers and prospective males. This analysis of population dynamics is needed to determine the amount of livestock expenditure from the area so that there is no 


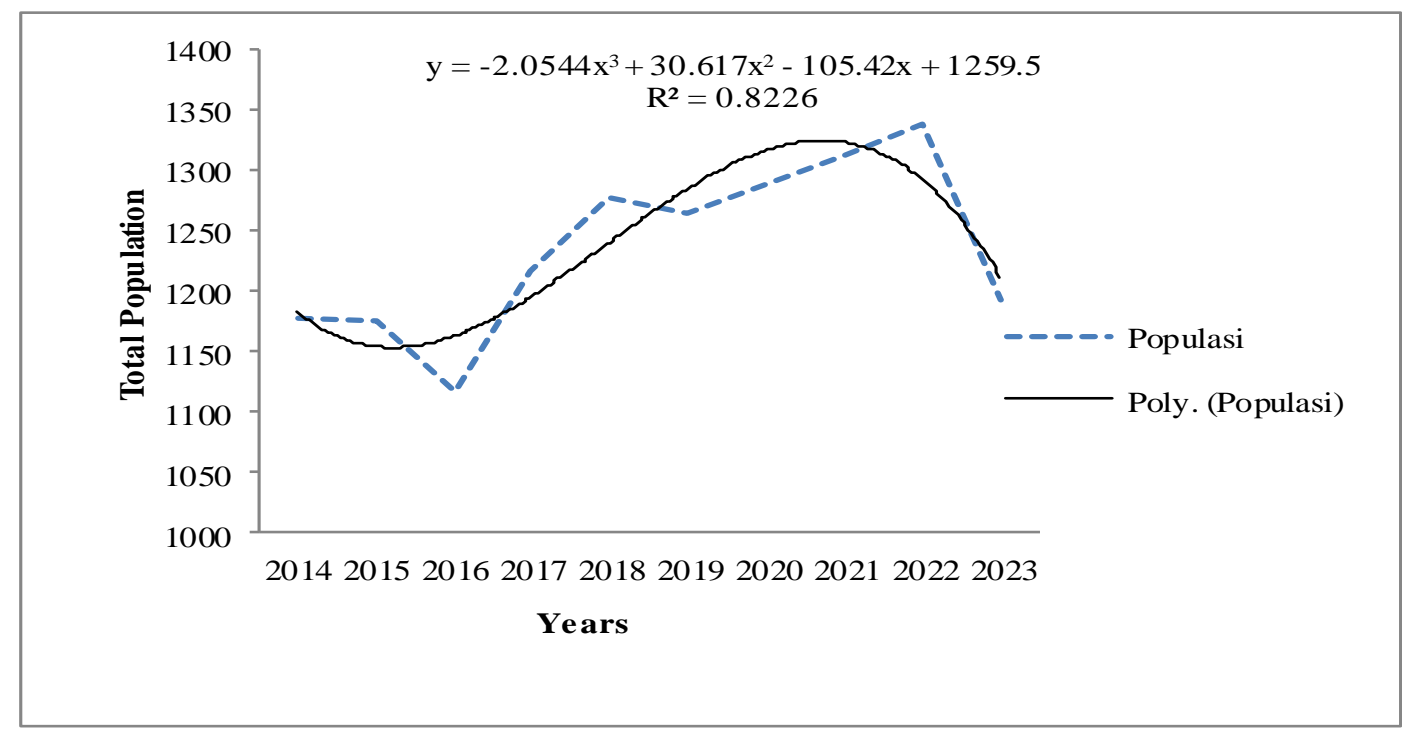

Figure 3. Prediction population $n$ of Kuantan cattle in Kuantan Regency, Indonesia

depletion of the population (Fioretti et al. 2020). The population dynamics of Kuantan cattle were different from those of native cattle (Sylhet) Bangladesh (Koirala et al. 2011); Pasundan cattle (Said et al. 2017) and breed Ongole cattle (Rohyan et al. 2016).

\section{CONCLUSION}

The reproductive efficiency of Kuantan cattle was $1.04 \%$, natural increase $5.14 \%$, male and female counterpart 1: 5 , the NRR of male $50 \%$, and female $100.56 \%$, total cattle out $18.69 \%$ and total livestock intake $18.69 \%$, output $48.88 \%$ and estimated population dynamics $2.85 \%$. It is recommended not to release Kuantan cattle in the next 5 years to maintain population balance.

\section{ACKNOWLEDGMENT}

Thanks to the Rector of UIN Suska Riau for providing funding support in this study, the farmers who became the study sample, the Departement Animal Husbandry and Agriculture Kuansing Regency and field officers.

\section{REFERENCES}

Agung PP, Saputra F, Zein MSA, Wulandari AS, Putra WPB, Said S, Jakaria J. 2019. Genetic diversity of Indonesian cattle breeds based on microsatellite markers. AJAS. 32: $467-476$

Bindari YR, Shrestha S, Shrestha N, Gaire TN. 2013. Effects of nutrition on hematology of rabbits: a review. European Sci. J. 10:421-429.
Budiarto A, Hakim L, Suyadi, Nurgiartiningsih VM, Ciptadi G. 2013. Natural increase Sapi Bali di Wilayah instalasi populasi Dasar Propinsi Bali. Ternak Tropika. 14:4652.

Department of Animal Husbandry and Animal Health Riau Province. 2019. Laporan Tahunan Dinas Peternakan Dan Kesehatan Hewan Provinsi Riau. Pekanbaru (Indones): Department of Animal Husbandry and Animal Health Riau Province.

Fioretti M, Negrini R, Biffani S, Quaglia A, Valentini A, Nardone A. 2020. Demographic structure and population dynamics of Maremmana cattle local breed after 35 years of traditional selection. Livest. Sci. 232:19.

Ferraz PC, Malhado CHM, Ramos AA, Carneiro PLS, Carrillo JA, Malhado ACM. 2015. Population structure and genetic variability of a closed Jaffarabadi buffalo herd from Brazil. Buffalo Bul. 34:197-207.

Gunawan A, Sari R, Parwoto Y, Uddin MJ. 2011. Nongenetic factors effect on reproductive performance and preweaning mortality from artificially and naturally bred in Bali Cattle. J Indonesia Trop. Agric. 36:83-90

Hidayati, Misrianti R, Ali A. 2016. Phylogenetic tree of Kuantan cattle by DNA barcoding. JITV. 21:41-48.

Jiyanto, Anwar P. 2019. Identifikasi kualitas spermatozoa Sapi Kuantan Riau sebagai pelestarian plasma nutfah ternak lokal. J Ilmu Teknol. Peternak. Trop. 6:52-56.

Koirala B, Alam MZ, Iqbal A, Bhuiyan AKFH. 2011. Study on morphometric, Productive and Reproductive Traits of Native Cattle at Sylhet District. J Bangladesh Agril Univ. 9:85-89

Kusuma SB, Ngadiyono N, \& Sumadi S. 2017. Estimasi Dinamika populasi dan penampilan reproduksi Sapi Peranakan Ongole di Kabupaten Kebumen Provinsi Jawa Tengah. Bul. Peternak. 41:230-242. 
Kutsiyah F . 2017. Dinamika populasi dan produktivitas Sapi Madura di wilayah konservasi Pulau. Sains Peternak. 15: 70-77.

Makina SO, Taylor JF, Van Marle-Köster E, Muchadeyi FC, Makgahlela ML, MacNeil MD, Maiwashe A. 2015. Extent of linkage disequilibrium and effective population size in four South African Sanga cattle breeds. Frontiers Gen. 6:1-12.

Pribadi LW, Maylinda S, Nasich M, Suyadi S. 2015. Reproductive efficiency of Bali cattle and it's crosses with Simmental breed in the lowland and highland areas of West Nusa Tenggara Province, Indonesia. LRRD. 27:

Putra DE, Anwar S, Afriani T. 2017. The estimation potential livestock breeding of buffalo in Ulakan Tapakis District, Padang Pariaman Regency, West Sumatra. J Vet. 18:624.

Putra D, Sumadi, Hartatik T. 2015. Estimasi output sapi potong di Kabupaten Pesisir Selatan Provinsi Sumatera Barat. JPI. 17:105-115.

Rohyan J, Sutopo, Kurnianto E. 2016. Population dynamics on Ongole Grade Cattle in Kebumen Regency-Central Java. JITAA. 41:224-232.

Romjali E. 2018. Local beef cattle breeding program in Indonesia. Wartazoa. 28:199-210.

Said S, Pintaka W, Putra B, Anwar S, Agung PP, Yuhani H. 2017. Phenotypic, morphometric characterization and population structure of Pasundan cattle at West Java, Indonesia. Biodivers. 18:1638-1645.

Santana JL, Oliveira PS, Eler JP, Gutierrez JP, Ferraz JBS. 2012. Pedigree analysis and inbreeding depression on growth traits in Brazilian Marchigiana and Bonsmara breeds. JAS. 90:99-108

Samberi K, Ngadiyono YN, Sumadi. 2010. Estimasi dinamika populasi dan produktivitas sapi Bali di Kabupaten Kepulauan Yapen, Propinsi Papua. Bul. Peternak. 34:169-177.

Suyadi S, Hakim L, Wahjuningsih S, Nugroho H. 2014. Reproductive performance of Peranakan Ongole (PO) and Limousin $\mathrm{x}$ PO Crossbred (Limpo) Cattle at different altitude areas in East Java, Indonesia. JASA. 9:81-85.

Sumadi. 2001. Estimasi dinamika populasi dan output kambing Peranakan Ettawah di Kabupaten Kulon Progo. Bul. Peternak. 25:161-171.

Sumadi, Hardjosubroto W, Prihadi S, \& Ngadiono N. 2002. Estimasi output kerbau di Kabupaten Demak Jawa Tengah Analisis dari segi pemuliaan dan produksi daging. Bul. Peternak. 26:27-38.

Syatra U, Kasim SN, Asnawi A. 2016. Pengaruh Pengetahuan, motivasi dan biaya inseminasi. JIIP. 3:7176 .

Tanari M, Duma Y, Rusiyantono Y, Mangun M. 2011. Dinamika Populasi sapi potong. J Agrisains. 12:24-29.

Warwick EJ, Astuti JM, Hardjosubroto W. 1983. Pemuliaan Ternak. Yogyakarta (Indonesia): Gadjah Mada University Press.

Wang J, Santiago E, Caballero A. 2016. Prediction and estimation of effective population size. Heredity. 117: 193-2006. 